\title{
The effects of job characteristics and individual characteristics on job satisfaction and burnout in community nursing
}

\section{PATRICK G. M. JANSEN, ${ }^{*}$ M.Sc., R.N.}

Department of Nursing and Caring Research, Netherlands Institute of Primary Health Care, Utrecht, and Management Consultant. Hoeksma Homans and Menting. Enschede. The Netherlands

\begin{abstract}
ADA KERKSTRA, Ph.D.
Department of Nursing and Caring Research, Netherlands Institute of Primary Health Care, Utrecht, The Netherlands
\end{abstract}

\section{HUDA HUIJER ABU-SAAD, Ph.D.}

Department of Nursing Science, University of Limburg, Maastricht, The Netherlands

\section{JOUKE VAN DER ZEE, Ph.D.}

Netherlands Institute of Primary Health Care, Utrecht, and Chair of Primary Health Care Research, Department of Medical Sociology, University of Limburg, Maastricht. The Netherlands

\begin{abstract}
The aim of this article is to describe job satisfaction and burnout among two categories of community-based nurses $(N=402)$ in the Netherlands taking account of job and individual characteristics. Results show that these nurses are moderately satisfied with their jobs and the effects of burnout are average. Further, community nurses are less satisfied and have experienced burnout to a greater extent than community nurse auxiliaries. Both job characteristics and individual characteristics are related to job satisfaction and burnout. However, job satisfaction is affected to a greater extent by job characteristics
\end{abstract}

* Address for correspondence: Netherlands Institute of Primary Health Care (NIVEL), P.O. Box 1568, 3500 BN Utrecht. The Netherlands. 
whereas burnout is more often a result of individual characteristics. As research in this area is scarce and home care is changing radically, these results may be valuable in coping with change without losing sight of nursing's professional values. Copyright (C) 1996 Elsevier Science Ltd.

\section{Introduction}

Home health care is changing. The number of the elderly demanding home care is growing. Technological changes make it possible to provide more complex nursing care at home which requires special expertise from the nurses. At the same time, governments demand a good price: quality ratio in care too (Turton, 1984; Taylor, 1985; Kenyon et al., 1990; Gibbs et al., 1991; Jansen and Kerkstra, 1993). Agencies for community nursing are being forced to use a more business-like approach. In the Netherlands, the reimbursement system has changed from budget- and input-financing to product- and output-financing. Furthermore, between 1988 and 1992 the employment of registered nurses decreased, whereas more nurses with lesser qualifications were employed by the agencies (Netherlands Central Bureau of Statistics, 1990, Netherlands Central Bureau of Statistics, 1994). Undoubtedly these changes will have consequences for nurses working in the community. To cope with the changes and guarantee quality of care, it is important to know how satisfied nurses are with their jobs, to what degree they experience burnout and what characteristics influence satisfaction and burnout. A review of the literature did not yield extensive information about job satisfaction and burnout in community nursing, making research in this area even more relcvant. Duc to the paucity of research in this area and because of the relevance of the problem for community nursing care, a research project was undertaken in the Netherlands which addressed the following research questions among others:

1. What are the differences in job characteristics, individual characteristics, job satisfaction and burnout between community nurses and community nurse auxiliaries?

2. What job characteristics are related to job satisfaction and burnout in community nursing, and are there differences in this between community nurses and community nurse auxiliaries?

3. What individual characteristics are related to job satisfaction and burnout in community nursing, and are there differences in this between community nurses and community nurse auxiliaries?

To answer these questions the model presented in Fig. 1 was used.

\section{Review of the literature}

\section{Types of community nurses in The Netherlands}

In the Netherlands a distinction is made based on the Dutch 'Nursing Profile' (National Council for Health Care, 1988) between two types of nurses in community nursing: community nurses and community nurse auxiliaries. In line with this profile, complexity of 

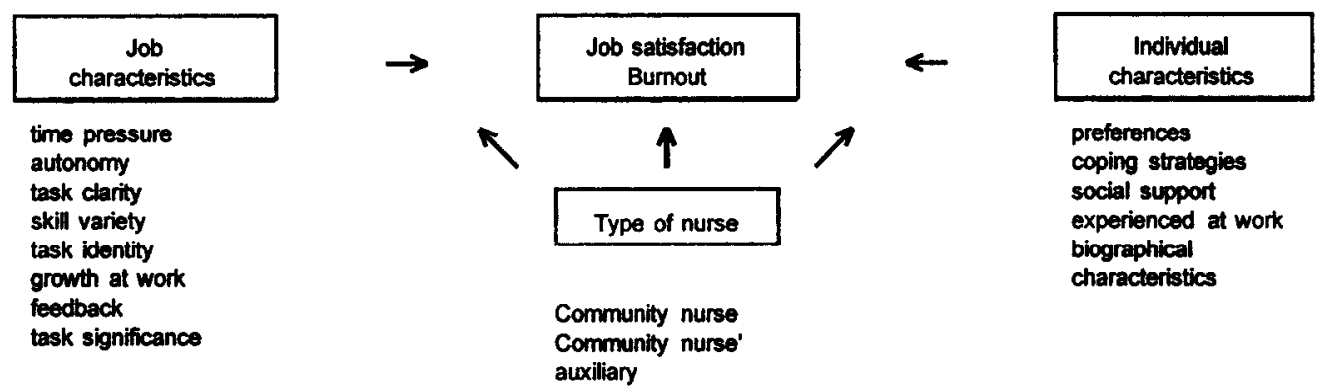

Fig. 1. Research model.

nursing care and the range of responsibilities are in most Dutch community nursing agencies used as the distinguishing characteristics between community nurses and community nurse auxiliaries (Jansen and Kerkstra, 1993). The different types of Dutch community nurses can be compared with the difference between the registered nurse and enrolled nurse in the United Kingdom (Verheij and Kerkstra, 1992) or between nurses with bachelor and associate degrees in the United States (American Organization of Nurse Executives, 1990). Professionally, there is a difference between nurses and nurse auxiliaries; but, hierarchically, they are both managed by a head nurse.

\section{Job satisfaction}

Different theoretical models can be used to measure job satisfaction. For example, the Job Characteristics Model (JC-Model) (Hackman and Oldham, 1980), the Job Demand Control Model (JDC-Model) (Karasek and Theorell, 1990) and the Demand Control Support Model (DCS-Model) (Johnson and Hall, 1988). The JC-Model was developed for redesigning work and shows that different job characteristics are related to job satisfaction: skill variety, task identity, task significance, autonomy and feedback. In the JDC-Model, psychological demands (workload) and decision latitude (autonomy) are the central components. Johnson and Hall (1988) added the dimension of social support to this model. Research showed that several of the factors mentioned in the models were related to job satisfaction among nurses. For example, a meta-analytic study (Blegen, 1993) identified thirteen variables that were often linked with nurses' job satisfaction. In this study, hospitals were the most common work sites. The results of this meta-analysis indicated that job satisfaction was most strongly and negatively related with stress and positively related to commitment. Autonomy, communication with supervisors, communication with peers, and recognition were moderately and positively related to job satisfaction. Low negative correlations were found between job satisfaction and locus of control, whereas fairness in reward distribution was positively related. Analyses of the demographic variables provided evidence for small but stable relationships between age, education and job satisfaction. Nurses who were older were more satisfied and the better educated were less satisfied with their work (Blegen, 1993). Boumans' study (1990) showed that, in addition to job characteristics, individual characteristics were also related to job satisfaction. She found that nurses who received a lot of social support at work were more satisfied, whereas nurses who prefered autonomy in their work and sought distraction when they were faced with problems were less satisfied with their jobs.

Only a few studies were found which focused on community nursing. The study of 
Parahoo and Barr (1994) showed that community nurses, working with people with a mental handicap, listed several factors that contributed to job satisfaction. These were: multi-disciplinary team work, involvement with clients, progress of clients, varied aspects of work, autonomy and appreciation of clients. Factors contributing to job dissatisfaction were: heavy caseload, administrative work, lack of resources, lack of communication, lack of recognition from other staff and lack of support from management. Seymour and Buscherhof (1991) found that dissatisfaction among nurses was mainly caused by structural problems (i.e. those created by inadequate working conditions and counterproductive attitudes within employing organizations) and bad remuneration and benefits. The study by Wade (1993) showed that there were differences in job satisfaction between types of nurse within community nursing. Practice nurses were significantly more satisfied with their jobs than district nurses and health visitors. Riordan (1991) collected data from a sample of community health, school health, and home health nurses. Prestige had the highest positive correlation with job satisfaction and regression analysis showed that this was the single significant predictor. The correlation matrix showed that three other subscales (autonomy, social interaction, and organizational requirements) correlated moderately and positively with job satisfaction. Weak positive relationships were found with years of work, years on the job, age, and years of education. Pay was not related to job satisfaction for these nurses. In comparing hospital-based nurses with home health nurses, research showed that home health nurses were more satisfied than hospital nurses with the opportunities to use their skills, participate in important and worthwhile activities, and in their overall feelings of self-fulfillment. In addition, home health care nurses were more satisfied with their opportunities to give a lead to others connected with their jobs, to share in deciding on methods and procedures, and with their opportunities to share in setting organizational goals (Curreri et al., 1985).

\section{Burnout}

Burnout is a negative experience and results from the interaction between the individual and the environment. Although a subjective phenomenon, burnout has a clear relationship with the organizational setting in which it occurs. In essence, burnout is a response to chronic occupational stress (Handy, 1988; Sullivan, 1993). Maslach and Jackson (1986) defined burnout as "a syndrome of emotional exhaustion, depersonalization and reduced personal accomplishment that can occur among individuals who do 'people work' of some kind". This definition includes three dimensions of burnout. Emotional exhaustion involves individuals feeling they are no longer able to give of themselves at a psychological level. Depersonalization refers to the development of negative, cynical attitudes and feelings about one's clients. Reduced personal accomplishment is the tendency to evaluate oneself negatively, particularly in relation to one's work with clients.

Review of the literature from Moore and Simendinger (1982) showed that factors contributing to occupational stress can be divided into three sources relating to the workplace (factors at the institutional-, unit-, and patient-level) and a fourth source focusing on stress at the personal level (Cohen-Mansfield, 1989). McGrath et al. (1989) showed that moderate or high stress levels in nursing were caused by having insufficient time to perform duties to the nurses satisfaction and to the rationing of scarce services or resources. In respect of the three burnout-dimensions, research among health care social workers showed that role conflict, role ambiguity, and lack of physical comfort were significantly related to emotional 
exhaustion. Depersonalization was related to high role conflict, low challenge, and low satisfaction with financial rewards. Significant job characteristics in the sense of personal accomplishment were: high challenge, high workload, greater satisfaction with financial rewards, low levels of role conflict, and low levels of conflict with professional values (Siefert et al., 1991). Among nurses, feelings of emotional exhaustion increased when the amount of workload increased. This relationship was reduced when nurses had more autonomy in their work. A negative relationship was found between the amount of challenge in the job and social support experienced and feelings of emotional exhaustion (De Jonge et al., 1994).

In addition to job characteristics, individual characteristics are related to burnout. The study of Boyle et al. (1991) among critical care nurses showed that personality hardiness, social support and ways of coping were rclated to burnout. Hardy persons have a higher sense of commitment to work and self and feel a greater sense of control over their lives, viewing stressors as potential opportunities for change. Social support had a negative relationship to burnout too. Both work-related and nonwork-related sources of social support were significantly negatively related to burnout. With respect to coping this study showed that problem-focused coping was not related to burnout, whereas use of emotionfocused coping was positively related to burnout. Peer-support and support from supervisors were the two most commonly reported factors that assisted nurses in coping with job-related stressful events (Boyle et al., 1991). Similar relations wcre found by Hare et al. (1988).

Only a few studies were found on community nursing. Responses of community health nurses identified major sources of stress as factors related to quantitative work overload, uncooperative family members and clients, unfamiliarity with situations, inability to reach physicians, and personal situations. The intensity of stressors was significantly different by age, in that older nurses experienced less stress (Walcott-McQuigg and Ervin, 1992). McGrath et al. (1989) showed that direct contact with patients and the emotional demands of patients caused community-based nurses more stress when compared with hospitalbased nurses. In another study, the stress experienced by community nurses decreased as the nurses: recognized an improvement in the quality of care the patient received; were given adequate time to manage the requirements of the job, or developed competency in the performance of the tasks assigned in the health setting (Boswell, 1992).

\section{Method}

\section{Subjects and procedure}

The subjects in this study were community nurses and community nurse auxiliaries employed by 10 agencies for community nursing scattered over the Netherlands. Three hundred and ten community nurses and 92 community nurse auxiliaries filled in a structured questionnaire out of the total group of 441 nurses. This led to a response-rate of $91 \%$. Seven percent of the nurses were male and $93 \%$ female. The distribution of age and employment of the subjects is presented in Table 1 .

The figures in Table 1 show that the majority of both community nurses and community nurse auxiliaries are between 31 and 40 years old, and that the nurses are older than the auxiliaries. The years of experience in home care are connected with this distribution of age. The community nurses in our sample have significantly more experience in home care than the community nurse auxiliaries: the mean scores are 8.5 and 5.4 years, respectively. 
Table 1. Distribution of age and employment (hours per week)

\begin{tabular}{|c|c|c|c|c|}
\hline & $\begin{array}{l}\text { Total group } \\
(N=402)\end{array}$ & $\begin{array}{l}\text { Community nurses } \\
(N=310)\end{array}$ & \multicolumn{2}{|c|}{$\begin{array}{l}\text { Community nurse auxiliaries } \\
(N=92)\end{array}$} \\
\hline \multicolumn{5}{|c|}{ Distribution of age: } \\
\hline $20-30$ years & $28.8 \%$ & $26.9 \%$ & $35.9 \%$ & \\
\hline $31-40$ years & $37.6 \%$ & $36.7 \%$ & $44.5 \%$ & \\
\hline 41-50 years & $24.6 \%$ & $24.9 \%$ & $17.4 \%$ & \\
\hline $51-60$ years & $9.0 \%$ & $11.5 \%$ & $2.2 \%$ & \\
\hline Meanl age & 36.8 years & 37.7 years**** & 33.9 years $* * *$ & ${ }^{* * *}(P \leq 0.001)$ \\
\hline \multicolumn{5}{|c|}{ Employment (hours per week): } \\
\hline $0-20$ hours & $14.6 \%$ & $14.0 \%$ & $16.3 \%$ & \\
\hline 21-30 hours & $24.2 \%$ & $19.2 \%$ & $34.8 \%$ & \\
\hline 31-37 hours & $39.8 \%$ & $41.4 \%$ & $36.9 \%$ & \\
\hline 38 hours & $21.4 \%$ & $25.4 \%$ & $12.0 \%$ & \\
\hline Mean hours & 29.8 hours & 30.4 hours $^{* *}$ & 28.0 hours** & ${ }^{* *}(P \leq 0.01)$ \\
\hline
\end{tabular}

Compared with a representative study of the work of community nurses and auxiliaries in the Netherlands (Vorst-Thijssen et al., 1990), in our sample, nurses between 20 and 30 years of age were less well represented and nurses between 41 and 50 years were better represented. Consequently the subjects in our sample were relatively old and had a lot of experience in home care. The second part of Table 1 shows that, in our sample, nurses were employed for more hours than nurse auxiliaries. This is comparable with national figures: in 1992, $22 \%$ of the nurses and $13 \%$ of the auxiliaries were employed for 38 hours per week (Netherlands Central Bureau of Statistics, 1994).

\section{Measuring instruments}

A questionnaire was developed based on the Algera questionnaire (Algera, 1980; Algera et al., 1986) to characterize the nursing roles and measuring job satisfaction. Algera modified and enlarged the Job Diagnostic Survey (Hackman and Oldham, 1980). Prior to the research conducted by the authors of this article, Boumans (1990) used the Algera questionnaire for nurses in hospitals. Based on these results, a questionnaire was constructed to assess eight job characteristics (measured by 24 items): time pressure, autonomy, job clarity, skill variety, task identity (the degree to which a job requires completion of a whole and identifiable piece of work, i.e. doing assessments and diagnostics), possibilities for growth at work, feedback and task significance (i.e. the degree to which the job has a substantial impact on the lives of other people in the immediate organization and in the world at large). Cronbach's $\alpha$ of the subscales ranged from 0.67 to 0.79 .

Several individual characteristics were measured: preferences, coping strategies, experienced social support and biographical characteristics. Preferences were measured by six subscales (33 items): preference for career, prestige, autonomy, co-operation, variety and absence of time pressure. The internal consistency of each subscale was high (Cronbach's $\alpha$ ranged from 0.75 to 0.93 ). To measure coping strategies the Utrecht Coping List (UCL) (Schreurs et al., 1988) was used. This questionnaire consists of three subscales: an active way of handling problems (seven items, $\alpha=0.76$ ), remaining passive ( 11 items, $\alpha=0.71$ ) and seeking social support (six items, $\alpha=0.80$ ). Social support experienced at work was measured by the Organizational Stress Questionnaire (VOS-D) (Bergers et al., 1986) including two subscales: social support received from the supervisor $(\alpha=0.91)$ and social support 
received from peers $(\alpha=0.71)$. Finally, three biographical characteristics were used in this study: age, sex and hours of employment. These biographical characteristics, together with the variable 'type of nurse' are used as control variables in the regression analysis. In other studies similar control variables were used (Boumans, 1990; Le Blanc, 1994).

Based on the study of Boumans (1990), job satisfaction was measured by eight subscales (measured by 43 items): satisfaction with the quality of care, general work satisfaction, supervisory satisfaction, satisfaction with peers, patient-contact, patient-assignment, clarity and growth at work. The internal consistency of each subscale was acceptable to high (Cronbach's $\alpha$ ranged from 0.64 to 0.92 ). In this article the overall score is taken into account $(\alpha=0.70)$.

To measure burnout the Dutch version of the Maslach Burnout Inventory (MBI-NL) was used (Schaufeli and Van Dierendonck, 1994). The MBI-NL consists of three subscales designed to assess the frequency (how often persons have these feelings) of three aspects of burnout: emotional exhaustion, depersonalization and personal accomplishment. A high degree of burnout was reflected in high scores on the emotional exhaustion and depersonalization subscales and in low scores on the personal accomplishment subscale. The inventory is self-administered and the frequency with which the respondents experience feelings related to each subscale is assessed in terms of 22 7-point Likert-type questions $(0=$ ncver, $6=$ always). Items 12 and 16 were not included because other studies showed that these items do not load on one factor only (Schaufeli and Van Dierendonck, 1994). Eight items assess emotional exhaustion, depersonalization is measured by five items and seven items assess feelings of personal accomplishment. The internal consistency of each subscale is acceptable to high (Cronbach's $\alpha$ is, respectively, $0.86,0.64$ and 0.77 ). To get a better idea of the scores on the three dimensions a comparison was made with a 'standard for nurses' presented in the study by Schaufeli and Van Dierendonck (1994). In that study scores from 2500 nurses in the Netherlands were analyzed and the mean scores on the three dimensions were presented as the standard. The authors emphasize that these standards are not yet definitive. On a scale from 0 to 6 for emotional exhaustion the standard is 1.9 (scores between 1.1 and 2.5 are average), for depersonalization the standard is 1.4 (scores between 0.6 and 1.8 are average), and for personal accomplishment the standard is 3.9 (scores between 3.4 and 4.3 are average).

Mean scores were calculated and regression analysis was carried out to analyse the data. To measure whether there were significant differences in effects of the characteristics on job satisfaction and burnout between nurses and auxiliaries, the $\beta \mathrm{s}$ in the regression analysis were further analyzed. Owing to multicollincality, it was not possible to use interactionvariables in the analysis. And as it is incorrect just to compare the size of the $\beta \mathrm{s}$ of the two groups (with different sample sizes) we were forced to use another method. Accordingly the $t$-test for difference in coefficients from separate subgroup regressions was used (Hardy, 1993).

\section{Results}

Differences in mean-scores on the variables between the two types of nurses

First, the means of all variables are presented in Table 2. For all variables it is considered that a higher score means that the variable is present to a higher extent. $t$-Tests were used 
Table 2. Mean scores and standard deviations of all variables

\begin{tabular}{|c|c|c|c|c|}
\hline \multirow[b]{2}{*}{ Variables } & \multicolumn{2}{|c|}{ Community nurses $(N=310)$} & \multicolumn{2}{|c|}{ Community nurse auxiliaries ( $N=92$ ) } \\
\hline & Mean & SD & Mean & $\mathrm{SD}$ \\
\hline \multicolumn{5}{|c|}{ Job characteristics (scale 1-7): } \\
\hline Time pressure & $5.13^{* *}$ & 1.13 & $4.75^{* *}$ & 1.08 \\
\hline Autonomy & 4.35 & 1.23 & 4.62 & 1.29 \\
\hline Task clarity & 5.86 & 0.60 & 5.91 & 0.62 \\
\hline Skill variety & $5.27^{* *}$ & 0.78 & $4.98^{* *}$ & 0.81 \\
\hline Task identity & $5.32^{* * *}$ & 1.76 & $2.20^{* * * *}$ & 1.09 \\
\hline Growth at work & 4.09 & 1.38 & 4.18 & 1.25 \\
\hline Feedback & $4.38^{* *}$ & 0.90 & $4.70^{* *}$ & 0.85 \\
\hline Task significance & 5.22 & 0.68 & 5.36 & 0.79 \\
\hline \multicolumn{5}{|l|}{ Individual characteristics: } \\
\hline \multicolumn{2}{|l|}{ Preferences for (scale 1-5): } & 0.84 & 3.42 & 0.85 \\
\hline $\begin{array}{l}\text { Career } \\
\text { Prestige }\end{array}$ & 3.43 & 0.65 & 3.43 & 0.67 \\
\hline Autonomy & $3.74 * *$ & 0.57 & $3.56^{* *}$ & 0.54 \\
\hline Co-operation & 3.47 & 0.56 & 3.46 & 0.57 \\
\hline Skill variety & 3.82 & 0.56 & 3.72 & 0.55 \\
\hline Absence of time pressure & 3.84 & 0.57 & 3.78 & 0.60 \\
\hline \multicolumn{5}{|l|}{ Coping strategies (scale 1-4): } \\
\hline Active approach & 2.95 & 0.41 & 2.89 & 0.39 \\
\hline Passive approach & 1.96 & 0.31 & 1.92 & 0.34 \\
\hline Seeking social support & 2.65 & 0.48 & 2.59 & 0.49 \\
\hline \multicolumn{5}{|c|}{ Social support experienced from (scale 1-4): } \\
\hline Head nurse & $2.90^{* *}$ & 0.76 & $3.16^{* *}$ & 0.60 \\
\hline Peers & 3.29 & 0.37 & 3.37 & 0.37 \\
\hline \multicolumn{5}{|l|}{ Job satisfaction (scale 1-5): } \\
\hline Overall score & $3.55^{* * *}$ & 0.36 & $3.72^{* * *}$ & 0.32 \\
\hline With quality of care & 3.55 & 0.55 & 3.61 & 0.47 \\
\hline General work satisfaction & $3.68^{* * *}$ & 0.65 & $3.96^{* * *}$ & 0.63 \\
\hline Supervisory satisfaction & $3.21^{* * *}$ & 0.85 & $3.56^{* * *}$ & 0.70 \\
\hline With peers & 3.85 & 0.45 & 3.86 & 0.49 \\
\hline With patient-contacts & $3.80^{*}$ & 0.42 & $3.91^{*}$ & 0.40 \\
\hline With patient-assignment & 3.24 & 0.85 & 3.14 & 0.84 \\
\hline With clarity & $3.41^{* * *}$ & 0.48 & $3.64^{* * *}$ & 0.41 \\
\hline With growth at work & $3.35^{* * * *}$ & 0.72 & $3.63^{* * * *}$ & 0.54 \\
\hline \multicolumn{5}{|c|}{ Burnout dimensions (scale 0-6): } \\
\hline Emotional exhaustion & $2.15^{*}$ & 0.84 & $1.93^{*}$ & 0.84 \\
\hline Depersonalization & $1.15^{*}$ & 0.68 & $0.95^{*}$ & 0.75 \\
\hline Personal accomplishment & $4.04^{*}$ & 0.47 & $4.17^{*}$ & 0.51 \\
\hline
\end{tabular}

${ }^{*} P \leq 0.05,{ }^{* *} P \leq 0.01,{ }^{* * *} P \leq 0.001$.

to decide if differences between community nurses and community nurse auxiliaries were significant.

Table 2 shows at first that there are differences in job characteristics between the two types of nurses. Community nurses are subject to a greater pressure in respect of time, the variety and the nature of their work (i.e. doing assessments and diagnostics) is greater and they receive less feedback than nurse auxiliaries. The great difference in scores on 'task identity' prevented this variable from being included in the regression analysis: $9 \%$ of the nurses versus $62 \%$ of the auxiliaries scored 1 or 2 , whereas $67 \%$ of the nurses versus $1 \%$ of the auxiliaries scored 5,6 or 7 . Inclusion of this variable would contribute nothing to the effects of making assessments and diagnostic work but only provide information about the effects of being a nurse or an auxiliary. In addition to these job characteristics, the 
nurses and auxiliaries differed on two individual characteristics: nurses do prefer autonomy in their work to a greater extent, and auxiliaries do receive more social support from their head nurses. In respect of job satisfaction, the data show that both types of nurses are moderately satisfied. On a 5-point scale, the mean scores varied between 3.14 and 3.96 . The data also showed that community nurse auxiliaries were overall better satisfied than community nurses. The scores on the subscales show that this difference occurs in different aspects. Compared with registered nurses, nurse auxiliaries experience more satisfaction with their work in general, are more satisfied with their head nurse and the contacts with patients. They are also more satisfied with the clarity of their job description and opportunities for growth at work. Finally, the burnout-scores show that there are significant differences between nurses and auxiliaries on all three dimensions. Nurse auxiliaries are significantly less emotionally exhausted and depersonalized than nurses and feel themselves more competent personally for the work they are doing.

\section{Effects of job characteristics on job satisfaction and burnout}

Table 3 presents the results of regression analysis with the job characteristics as independent variables. Two stages were used to build the regression models. In the first stage, four control variables were entered followed by the job characteristics in the second stage. In comparing the Adjusted $\mathrm{R}^{2}$ between the two stages it will be obvious to what extent the two groups of variables contribute to the model. Both stages include forced entry. This means that all variables presented in the table are included in every model. In the table, only the $\beta$ s at a significant level in the final model are presented.

Job satisfaction was related to the type of nurse and hours of employment: community nurses were less satisfied than auxiliaries and those who were employed for more hours are less satisfied with their work. These variables explain $7 \%$ of the variance. In addition to these control variables several job characteristics were related to job satisfaction as well: growth at work, feedback, task clarity and skill variety. The percentage of explained

Table 3. Results of regression analysis for job satisfaction and burnout with job characteristics as independent variables among the total group $(N=402)$

\begin{tabular}{|c|c|c|c|c|}
\hline & $\begin{array}{l}\text { Job } \\
\text { satisfaction }\end{array}$ & $\begin{array}{l}\text { Fmotional } \\
\text { exhaustion }\end{array}$ & $\begin{array}{l}\text { Depersonal- } \\
\text { ization }\end{array}$ & $\begin{array}{l}\text { Personal } \\
\text { accomplishment }\end{array}$ \\
\hline \multicolumn{5}{|l|}{ 1) Control variables: } \\
\hline Type of nurse & $-0.14^{*+* *}$ & - & $0.11^{*}$ & -. \\
\hline Age & $\cdots$ & $0.11^{*}$ & - & - \\
\hline Sex ${ }^{b}$ & - & - & - & - \\
\hline Hours of employment & $-0.14^{*}$ & $0.17^{* *}$ & -- & - \\
\hline Adj $R^{2}$ Change & 0.07 & 0.03 & 0.02 & 0.00 \\
\hline \multicolumn{5}{|l|}{ 2) Job characteristics: } \\
\hline Time pressure & - & $0.18 * *$ & - & -- \\
\hline Autonomy & - & $-0.16^{* *}$ & $-0.15^{* *}$ & - \\
\hline Task clarity & $0.11^{*}$ & - & - & - \\
\hline Skill variety & $0.11^{*}$ & - & $-0.13^{*}$ & - \\
\hline Growth at work & $0.26^{* * *}$ & - & - & - \\
\hline Feedback & $0.27^{* * *}$ & - & - & - \\
\hline Task significance & - & - & $-0.23^{* *}$ & $0.38^{* * *}$ \\
\hline Adj $R^{2}$ Change & 0.36 & 0.12 & 0.10 & 0.16 \\
\hline Total Adj R $\mathbf{R}^{2}$ & 0.43 & 0.15 & 0.12 & 0.16 \\
\hline
\end{tabular}

${ }^{a} 0=$ community nurse auxiliary, $1=$ community nurse. ${ }^{b} 0=$ male, $1=$ female. ${ }^{*} P \leq 0.05,{ }^{* *} P \leq 0.01,{ }^{* * *} P \leq 0.001$. 
variance by all the variables is moderately high (43\%). If the data are analyzed for the two types of nurses separately, no significant differences were found. In interpreting the regression analysis for burnout, it is important to rccall that high burnout was reflected in high scores in emotional exhaustion and depersonalization and in low scores in personal accomplishment. Three control variables affect burnout: community nurses experience more depersonalization and nurses who are older and work more hours are more emotionally exhausted. Several job characteristics also affect burnout: pressure of time increases feelings of burnout, whereas autonomy, skill variety and task significance reduce feelings of burnout. Compared with job satisfaction the job characteristics explain less of the variance in the models with the burnout-dimensions (between 12 and 16\%). Separate analysis did not yield significant differences in related characteristics between the two types of nurses.

\section{Effects of individual characteristics on job satisfaction and burnout}

The results of regression analysis with individual characteristics as independent variables are presented in Table 4. Looking at the effects of the control variables, the $\beta$ s show that there are some differences compared with Table 3. Especially in terms of the three burnoutdimensions Table 4 shows that the control variables more often reach the significance level. It shows that the effects of the control variables are dependent on the other variables in the model.

Several individual characteristics were related to job satisfaction. Persons who prefer prestige and skill variety are more satisfied, whereas preference for career has a negative influence on job satisfaction in community nursing. Further, social support received from the head nurse and peers has a positive influence on job satisfaction. Again, the percentage of explained variance of the final model is moderately high $(31 \%)$ but less than the model

Table 4. Results of regression analysis for job satisfaction and burnout with individual characteristics as independent variables among the total group $(N=402)$

\begin{tabular}{|c|c|c|c|c|}
\hline & $\begin{array}{l}\text { Job } \\
\text { satisfaction }\end{array}$ & $\begin{array}{l}\text { Emotional } \\
\text { exhaustion }\end{array}$ & $\begin{array}{l}\text { Depersonal- } \\
\text { ization }\end{array}$ & $\begin{array}{l}\text { Personal } \\
\text { accomplishment }\end{array}$ \\
\hline \multicolumn{5}{|l|}{ 1) Control variables: } \\
\hline Type of nurse ${ }^{a}$ & $-0.14^{* *}$ & - & $0.13^{*}$ & $-0.11^{*}$ \\
\hline Age & - & - & $-0.12^{*}$ & - \\
\hline $\operatorname{Sex}^{\mathrm{b}}$ & - & - & - & - \\
\hline Hours of employment & $\ldots$ & $0.20^{* * *}$ & $0.12^{*}$ & - \\
\hline Adj $R^{2}$ Change & 0.06 & 0.05 & 0.02 & 0.00 \\
\hline \multicolumn{5}{|l|}{ 2) Individual characteristics: } \\
\hline Preference for career & $-0.23^{* * *}$ & -- & - & - \\
\hline Preference for prestige & $0.17^{* *}$ & - & - & $0.13 *$ \\
\hline Preference for autonomy & - & - & $-0.15^{*}$ & - \\
\hline Preference for co-operation & - & - & $-0.14^{*}$ & - \\
\hline Preference for skill variety & $0.16 * *$ & $-0.16^{* *}$ & $-0.14^{*}$ & $0.13^{*}$ \\
\hline Preference for lack of time pressure & - & - & - & - \\
\hline Active approach & - & $-0.16^{* *}$ & - & $0.31^{* * *}$ \\
\hline Passive approach & - & $0.28^{* * *}$ & $0.24^{* * *}$ & $-0.18^{* * *}$ \\
\hline Seeking social support & $\ldots$ & - & - & - \\
\hline Support received from head nurse & $0.35^{* * *}$ & - & $-0.11^{*}$ & $0.16^{* * *}$ \\
\hline Support received from peers & $0.23^{* *}$ & $-0.21^{* *}$ & - & - \\
\hline Adj $\mathrm{R}^{2}$ Change & 0.25 & 0.21 & 0.16 & 0.30 \\
\hline Total Adj $\mathbf{R}^{2}$ & 0.31 & 0.26 & 0.18 & 0.30 \\
\hline
\end{tabular}

${ }^{\mathrm{a}} 0=$ community nurse auxiliary, $1=$ community nurse. ${ }^{\mathrm{b}} 0=$ male, $1=$ female. ${ }^{*} P \leq 0.05,{ }^{* *} P \leq 0.01,{ }^{* * *} P \leq 0.001$. 
with the job characteristics in Table 3. If regression analysis is done for the two types of nurses separately, some differences in the effects of the characteristics appeared. However, these differences proved not to be significant. In terms of burnout, almost all individual characteristics have an effect on one or more dimensions. Feelings of burnout are decreased by the following individual characteristics: preference for prestige, autonomy, co-operation and skill variety, an active approach to coping with problems and social support received from the head nurse and peers. Feelings of burnout are increased when a passive approach is used in coping with problems. The total Adjusted $\mathrm{R}^{2}$ shows that in terms of burnout, the individual characteristics explain a lot more of the variance (between 0.18 and 0.30 ) than the job characteristics (between 0.12 and 0.16 ). If regression analysis is done for the two types of nurses separately and the $\beta \mathrm{s}$ are compared, it appears that in respect of all the three burnout-dimensions, the support experienced from the head nurse has significantly more effect for nurse auxiliaries than for nurses. The other differences between the $\beta$ s were not significant.

Finally, the job characteristics and individual characteristics were included in one model. The results are presented in Table 5. The entering of characteristics was based on the Adjusted $\mathrm{R}^{2}$ in Table 3 and Table 4 . The control variables were entered for all the four models in the first stage. Because job satisfaction was influenced to a greater extent by job characteristics, all these characteristics were entered at the second stage and the individual characteristics that increased Adj $\mathbf{R}^{2}$ significantly, at the third stage. In terms of the three burnout-dimensions, all the individual characteristics were entered in the second step followed by the job characteristics that changed the Adj $\mathrm{R}^{2}$ significantly, in the third step. Table 5 shows that most effects presented before remain and that the total explained variance of all the four models increases significantly through moderate to high percentages when job and individual characteristics are put together in one model.

\section{Discussion}

The data presented in this article show that there are several significant differences in job and individual characteristics between community nurses and community nurse auxiliaries. These differences show on the one hand that the content of the work of community nurses is more attractive (they have higher scores on skill variety and task identity) but on the other hand nurses feel themselves more often on their own (they experience more time pressure, they get less feedback and they receive less support from their head nurse). Because the Dutch Nursing Profile (National Council for Health Carc, 1988) notes that assessment and diagnostics are reserved for nurses, it is not surprisingly that nurse auxiliaries score low on the variable 'task identity'. In respect of feedback the difference can be explained by the decreased involvement of head nurses in community nursing practice and the difference in responsibility between nurses and auxiliaries. Community nurses receive little feedback from their supervisor, whereas nurse auxiliaries can always receive feedback from the nurses. Because of their broader area of responsibility it is part of community nurses' job to supervise and give feedback to community nurse auxiliaries. In addition to less feedback (a job characteristic) the community nurses also receive less social support from their head nurse (an individual characteristic). In other words, when compared with auxiliaries, community nurses are less satisfied with the content of feedback they receive from their head nurse.

The scores on job satisfaction showed that executives in community nursing are mod- 
Table 5. The effects of job characteristics and individual characteristics on job satisfaction and burnout in one model

\begin{tabular}{|c|c|c|c|c|}
\hline & Iob satisfaction ${ }^{\prime \prime}$ & $\begin{array}{l}\text { Emotional } \\
\text { exhaustion }^{\mathrm{b}}\end{array}$ & $\begin{array}{l}\text { Depersonaliza- } \\
\text { tion' }^{\mathbf{b}}\end{array}$ & $\begin{array}{l}\text { Personal } \\
\text { accomplishment }\end{array}$ \\
\hline \multicolumn{5}{|l|}{ Control variables: } \\
\hline Type of nurse ${ }^{c}$ & $-0.09^{*}$ & - & - & - \\
\hline Age & - & - & - & - \\
\hline $\operatorname{Sex}^{d}$ & - & - & - & - \\
\hline Hours of employment & $-0.10^{*}$ & $0.15^{*+*}$ & $0.11^{*}$ & - \\
\hline \multirow{2}{*}{\multicolumn{5}{|c|}{ Job characteristics: }} \\
\hline & & & & \\
\hline Time pressure & $-0.11^{*}$ & $0.21^{* * *}$ & & $-\overline{c o *}$ \\
\hline Autonomy & - & $-0.14^{* *}$ & $-0.16^{* *}$ & $0.15^{* *}$ \\
\hline Task clarity & - & - & - & - \\
\hline Skill variety & $0.13^{*}$ & $0.13^{*}$ & - & - \\
\hline Growth at work & $0.24^{*+* *}$ & $-0.15^{* *}$ & - & - \\
\hline Feedback & $0.20^{* * *}$ & - & - & - \\
\hline Task significance & $0.11^{*}$ & - & $-0.15^{* *}$ & $0.26^{* * *}$ \\
\hline Adj $R^{2}$ change & 0.37 & 0.12 & 0.04 & 0.08 \\
\hline \multicolumn{5}{|l|}{ Individual characteristics: } \\
\hline Preference for career & $-0.16^{* * *}$ & - & - & - \\
\hline Preference for prestige & - & - & - & - \\
\hline Preference for autonomy & - & - & $-0.16^{* *}$ & - \\
\hline Preference for co-operation & - & - & $-0.17^{* *}$ & - \\
\hline Preference for skill variety & $0.12^{* *}$ & $-0.17^{* *}$ & - & $0.12^{*}$ \\
\hline Preference for lack of time pressure & - & $0.11^{*}$ & - & - \\
\hline Active approach & $-\ldots$ & $-0.17^{* *}$ & - & $0.25^{* * *}$ \\
\hline Passive approach & - & $0.25^{* * *}$ & $0.24^{* * *}$ & $-0.15^{* *}$ \\
\hline Seeking social support & - & - & - & - \\
\hline Support received from head nurse & $0.27^{* * * *}$ & - & $-0.11^{*}$ & $0.13^{* *}$ \\
\hline Support received from peers & $0.13^{* *}$ & $-0.25^{* * *}$ & - & - \\
\hline Adj $R^{2}$ change & 0.17 & 0.19 & 0.17 & 0.29 \\
\hline Total Adj $R^{2}$ & 0.54 & 0.35 & 0.23 & 0.37 \\
\hline
\end{tabular}

${ }^{a}$ At the first stage all the control variables were entered, at the stage step all the job characteristics and at the third stage the method 'forward' was used to select the individual characteristics that increased Adj $R^{2}$ significantly.

${ }^{b}$ At the first stage all the control variables were entered, at the second stage all the individual characteristics and at the third stage the method 'forward' was used to select the job characteristics that increased Adj $R^{2}$ significantly. ${ }^{\mathrm{c}} 0=$ community nurse auxiliary, $1=$ community nurse. ${ }^{\mathrm{d}} 0=$ male, $1=$ female. ${ }^{*} P \leq 0.05,{ }^{* *} P \leq 0.01,{ }^{* * *} P \leq 0.001$.

erately satisfied with their job. These scores are comparable with the results of a study among nurses working in Dutch hospitals (Boumans, 1990) and in community nursing in the United Kingdom (McGrath et al., 1989; Wade, 1993). When the nurses and auxiliaries are compared the results showed that community nurses are less satisfied with their work in general, their head nurse, clarity and opportunities for growth at work. Furthermore, community nurses manifest more feelings of burnout. The difference in satisfaction between the two types of nurse is consistent with the result of the meta-analysis of Blegen (1991) that nurses with a higher level of education are less satisfied with their work. The lower scores on job satisfaction and more feelings of burnout among community nurses reflect an important issue that is under discussion in Dutch community nursing. Since practice shows that most clients ask for basic carc requiring basic expertise that can be delivered by community nurse auxiliaries. However, most agencies still employ more community nurses than community nurse auxiliaries. Consequently the community nurses perform a lot of 
tasks below their level of training and skill and it is not always obvious when the specific expertise of a nurse is required (Jansen and Kerkstra, 1993).

Several job characteristics were shown to be related to job satisfaction and burnout. Job satisfaction is positively affected by task clarity, skill variety, possibilities for growth and feedback at work. The effect of feedback is consistent with the study of Blegen (1993): communication with supervisor and peers is positively related to job satisfaction. When compared with the differences in job characteristics, it seems that the difference in job satisfaction is caused by the fact that nurses receive less feedback than auxiliaries. Although nurses do have more variety in their work, this characteristic is apparently less important for job satisfaction.

In our study autonomy was not significantly related to job satisfaction. The reason for this could be the fact that nurses working in the community are relatively autonomous and thus this characteristic is not so important for job satisfaction. This explanation is supported by the study of Parahoo and Barr (1994): autonomy was listed by only eight of the 35 community nurses as factor that contributes to job satisfaction.

As regards burnout it became obvious that time pressure increases feelings of burnout, whereas burnout is decreased by autonomy, skill variety and task significance. The effect of time pressure and autonomy is supported by other studies (Siefert et al., 1991; De Jonge et al., 1994). If the differences in mean scores on these characteristics are taken into account, it seems that the higher feelings of burnout among nurses can be explained by the greater pressure of time they are under. Further analysis between nurses and auxiliaries did not show differences in the effects of job characteristics for job satisfaction and burnout.

Job satisfaction and burnout is also determined by individual characteristics. With exception of preference for career and a passive approach to coping with problems, all the individual characteristics have a positive influence on job satisfaction and decrease feelings of burnout. The social support received at work in particular is important in increasing job satisfaction and decreasing burnout. The effect of the coping-strategy is consistent with the studies of Hare et al. (1988), Boyle et al. (1991) and the importance of social support received at work is supported by the studies of Hare et al. (1988), McGrath et al. (1989), Boumans (1990) and Boyle et al. (1991). The greater feelings of burnout among community nurses seem to be the consequence of the fact that they feel themselves less supported by their head nurse. Further analysis showed that the support experienced from the head nurse in case of burnout was more important for nurse auxiliaries than for community nurses.

Finally, the results of regression analysis showed that job satisfaction is affected to greater extent by job characteristics, whereas burnout is more a result of individual characteristics. This is relevant in respect of the changes in home health care. As a result of projected demographic changes, the changing demands of health care services and the need for the cost-effective use of resources a new course for the development of the profession has been mapped (Gibbs et al., 1991). On the one hand the past decade has witnessed an increase in the employment of specialized nurses in primary health care to make more complex nursing care at home possible (Riportella-Muller et al., 1991; Bergen, 1991; Haste and MacDonald, 1992; Jansen and Kerkstra, 1993; Moons et al., 1994; Griffiths and Luker, 1994; WilsonBarnett and Beech, 1994). On the other hand, special attention is paid to skill mix or differentiated practice: the restructuring of roles and functions of nurses according to education, experience, and competence (Gibbs et al., 1991; American Organization of Nurse Executives, 1990; Martin and McGuire, 1990; Cowley, 1993; Jansen and Kerkstra, 1993; Heath, 1994). These changes will have consequences for the job characteristics in community 
nursing and consequently affect job satisfaction and burnout. These changes give opportunities for making their work more enjoyable, especially to community nurses. It is hypothesized on the results in this study, that these changes at work will mainly have consequences for job satisfaction. If organizations want to decrease feelings of burnout it is more effective to pay attention to supervisory support, peer relationships and individual trainingprogrammes instead of changing the work-content. The results of this study may be helpful in coping with the changes in community nursing.

\section{References}

Algera, J. A. (1980). Kenmerken van werk. Ph.D. thesis, University of Leiden.

Algera, J. A., Flier, H, van de and Kamp, L. J. T. van de (1986). Causal modelling of quality of work. In The Psychology of Work and Organization (Debus, C. and Schroiff, H. W., Eds). Elsevier Science Publishers, NorthHolland.

American Organization of Nurse Executives (1990). Current Issues and Perspectives on Differentiated Practice. American Hospital Association, Chicago.

Bergen, A. (1991). Nurses caring for the terminally ill in the community: a review of the literature. Int. J. Nurs. Stud. 28(1), 89-101.

Bergers, G. P. A., Marcelissen, F. G. H. and Wolf, de Ch. J. (1986). VOS-D Vragenlijst Organisatsiestress-D. Handleiding, Stressgroep publikatie 36.

Blegen, M. A. (1993). Nurses' job satisfaction: a meta-analysis of related variables. Nurs. Res. 42(1), 36-41.

Boswell, C. A. (1992). Work stress and job satisfaction for the community health nurse. J. Commun. Health Nurs. 9(4), 221-227.

Boumans, N. (1990). Het werk van verpleegkundige in algemene ziekenhuizen: een onderzoek naar werkaspecten en hun invloed op verpleegkundigen. University of Limburg, Maastricht.

Boyle, A., Grap, M. J., Younger, J, and Thornby, D. (1991). Personality hardiness, ways of coping, social support and burnout in critical care nurses. $J$. Adv. Nurs. 16, 850-857.

Cohen-Mansfield, J. (1989). Sources of satisfaction and stress in nursing home caregivers: preliminary results. $J$. Adv. Nurs. 14, 383-388.

Cowley, S. (1993). Skill mix: value for whom?. Health Visitor 66(5), 166-168.

Curreri, C. A., Gilley, W. F., Faulk, L. and Swansburg, R. C. (1985). Job satisfaction: hospital-based RNs versus home health care RNs. Nurs. Forum 22(4), 125-134.

Gibbs, I., McCaughan, D. and Griffiths, M. (1991). Skill mix in nursing: a selective review of the literature. $J$. Adv. Nurs. 16, 242-249.

Griffiths, J. and Luker, K. (1994). Community nurse attitudes to the clinical nurse specialist. Nurs. Times 90(17), $39-42$.

Hackman, J. R. and Oldham, G. R. (1980). Work Redesign. Addison-Wesley, Massachusetts.

Handy, J. A. (1988). Theoretical and methodological problems within occupational stress and burnout research. Hum. Relations 41(5), 351-369.

Hardy, M. A. (1993). Regression with dummy variables. Sage University Paper series on Quantitative Application in the Social Sciences, 07-093. Sage, Newbury Park, CA.

Hare, J., Pratt, C. C. and Andrews, D. (1988). Predictors of burnout in professional and paraprofessional nurses working in hospitals and nursing homes. Int. J. Nurs. Stud. 25(2), 105-115.

Haste, F. H. and MacDonald, L. D. (1992). The role of the specialist in community nursing: perceptions of specialist and district nurses. Int. J. Nurs. Stud. 29(1), 37-47.

Heath, I. (1994). Skill mix in primary care: should be used to match services to needs rather than to cut costs. $B r$. Med. J. 308, 993-994.

Jansen, P. G. M. and Kerkstra, A. (1993). Functiedifferentiatie binnen de thuiszorg. De functies van wijkverpleegkundige, wijkverpleegster en gezinsverzorgende nader omschreven. NIVEL, Utrecht.

Johnson, J. V. and Hall, E. M. (1988). Job strain, work place social support, and cardiovascular disease: a crosssectional study of a random sample of the Swedish working population. Am. J. Publ. Health 78(10), $1336-1342$.

de Jonge, J., Janssen, P. and Landeweerd, A. (1994). Effecten van werkdruk, autonomic en sociale ondersteuning op de werkbeleving van verplegenden en verzorgenden. Verpleegkunde 1, 17-26.

Karasek, R. A. and Theorell, T. (1990). Healthy Work: Stress, Productivity and the Reconstruction of Working Life. Basic Books, New York.

Kenyon, V., Smith, E., Hefty, I. V., Rell, M. I., McNeil, I. and Martaus, T. (1990). Clinical competencies for community health nursing. Publ. Health Nurs. 7(1), 33-39.

Le Blanc, P. M. (1994). De Steun van de Leiding. Een Onderzoek naar het Leader Meber Exchange Model in de Verpleging. Thesis Publishers, Amsterdam. 
Martin, S. D. and McGuire, M. (1990). A clinical ladder for the community health-care setting. J. Commun. Health Nurs. 7(4), 189-197.

Maslach, C. and Jackson, S. E. (1986). MBI: Maslach Burnout Inventory (manual research edition, 2nd Edn). Consulting Psychologists Press, Inc., Palo Alto.

McGrath, A., Reid, N. and Boore, J. (1989). Occupational stress in nursing. Int. J. Nurs. Stud. 26(4), 343-358.

Moons, M., Kerkstra, A. and Biewenga, T. (1994). Specialized home care for patients with AIDS: an experiment in Rotterdam, The Netherlands. J. Adv. Nurs. 19, 1132-1140.

Moore, T. F. and Simendinger, E. A. (1982). Organizational burnout: is your hospital on fire? Dimensions of Health Service 59, 17-18.

National Council for Health Care (1988). Verpleegkundige Beroepsprofiel. National Council for Health Care, Zoetermeer

Netherlands Central Bureau of Statistics (1990). Vademecum of Health Statistics of The Netherlands. Netherlands Central Bureau of Statistics, Voorburg/Heerlen.

Netherlands Central Bureau of Statistics (1994). Vademecum of Health Statistics of The Netherlands. Netherlands Central Bureau of Statistics, Voorburg/Heerlen.

Parahoo, K. and Barr, O. (1994). Job satisfaction of community nurses working with people with a mental handicap. J. Adv. Nurs. 20, 1046-1055.

Riordan. J. (1991). Prestige: key to job satisfaction for community health nurses. Publ. Health Nurs. 8(1), 59-64.

Riportella-Muller, R., Selby, M. L., Salmon, M. E., Quade, D. and Legault, C. (1991). Specialty roles in community health nursing: a national survey of educational needs. Publ. Health Nurs. 8(2), 81-89.

Schaufeli, W. and Dierendonck van, D. (1994). Burnout, een begrip gemeten. De Nederlands versie van de Maslach Burnout Inventory (MBI-NL). Gedray and Gezondheid 22(4), 153-171.

Schreurs, P. J. G., Willige, van de G., Tellegen, B. and Brosschot, J. F. (1988). De Utrechtse Coping Lijst: UCLhandleiding. Zwets \& Zeitlinger, Lisse.

Seymour, E. and Buscherhof, J. R. (1991). Sources and consequences of satisfaction and disstatisfaction in nursing: findings from a national sample. Int. J. Nurs. Stud. 28(2), 109-124.

Siefert, K., Jayaratne, S. and Chess, W. A. (1991). Job satisfaction, burnout, and turnover in health care social workers. Health and Social Work 16(3), 193-202.

Sullivan, P. J. (1993). Occupational stress in psychiatric nursing. J. Adv. Nurs. 18, 591-601.

Taylor, B. (1985). The effect of DRGs on home health care. New Jersey's experience suggests DRGs are increasing the need for home care for more acutely ill patients. Nurs. Outlook 33(6), 288-289.

Turton, P. (1984). Nurses working in the community. Nurs. Times 5, 40-42.

Verheij, R. A. and Kerkstra, A. (1992). International Comparitive Study of Community Nursing. Avebury, Aldershot.

Verran, J. A. and Reid, P. J. (1987). Replicated testing of the nursing technology model. Nurs. Res. 36(3), 190194.

Wade, B. E. (1993). The job satisfaction of health visitors, district nurses and practice nurses working in areas served by four trusts: year 1. J. Adv. Nurs. 18, 992-1004.

Walcott-McQuigg, J. A. and Ervin, N. E. (1992). Stressors in the workplace: community health nurses. Publ. Health Nurs. 9(1), 65-71.

Wilson-Barnett, J. and Beech, S. (1994). Evaluating the clinical nurse specialist. A review. Int. J. Nurs. Stud. 31(6), $561-571$. 